\title{
RADIOCARBON WIGGLE-MATCH DATING OF BULK SEDIMENTS-HOW ACCURATE CAN IT BE?
}

\author{
Anette Mellström ${ }^{1,2} \bullet$ Raimund Muscheler ${ }^{1}$ Ian Snowball ${ }^{1,3} \bullet$ Wenxin Ning $^{1}$ Eeva Haltia ${ }^{1}$ \\ ABSTRACT. We used the radiocarbon wiggle-match dating technique to date the varved sediments of Lake Gyltigesjön in \\ southern Sweden with the main aim to construct an accurate chronology covering the period between about 3000 and 2000 \\ cal BP. Wiggle-match dating was applied to bulk sediments to evaluate the possibility of constructing accurate chronologies \\ in the absence of terrestrial plant macrofossils and when the amount of old carbon in the sediments is unknown. Facilitated \\ by a floating varve chronology and relatively stable ${ }^{14} \mathrm{C}$ reservoir ages, the results show the possibility to assess the contri- \\ bution of old carbon solely based on the ${ }^{14} \mathrm{C}$ wiggle-matching of bulk sediments. We confirm the wiggle-matched chronology \\ and the ${ }^{14} \mathrm{C}$ reservoir age of approximately $260 \mathrm{yr}$ by cross-checking the results with ${ }^{14} \mathrm{C}$ dating of macrofossils. The obtained \\ calibrated ages based on bulk sediments have an uncertainty range of about $60-65 \mathrm{yr}$ ( $95.4 \%$ confidence interval). This study \\ confirms that ${ }^{14} \mathrm{C}$ wiggle-match dating of bulk sediments is a viable tool when constructing high-resolution chronologies. The \\ method is especially useful in Sun-climate studies since the timing between solar activity variations (expressed as ${ }^{14} \mathrm{C}$ varia- \\ tions) and climate changes can be accurately determined.
}

\section{INTRODUCTION}

Numerous natural archives indicate climatic changes that coincided with prominent fluctuations in the atmospheric ${ }^{14} \mathrm{C}$ concentration, raising hypotheses that causatively link the climatic changes to variable solar activity (e.g. Karlén and Kuylenstierna 1996; van Geel et al. 1999; Blaauw et al. 2004). However, in many cases insufficient chronological control limits the possibilities to compare paleoclimatic reconstructions with the external forces, and thereby restricts investigations of leads and lags in the climate system. Well-dated archives are, therefore, a crucial part of investigations of the timing between climate forcing and climate change. High-precision chronologies can be obtained by dating series of closely spaced samples with the ${ }^{14} \mathrm{C}$ wiggle-match dating technique (Pearson 1986). With this technique, the samples selected for dating are aimed to coincide with periods containing distinct wiggles in the ${ }^{14} \mathrm{C}$ calibration record. Thus, the rapid increases and decreases in atmospheric ${ }^{14} \mathrm{C}$ concentration are utilized to match sediment ages to the absolutely dated treering timescale that underlies the ${ }^{14} \mathrm{C}$ calibration record for the Holocene period (Reimer et al. 2009). The advantages of this method have been emphasized for decades (Pearson 1986; van Geel and Mook 1989) and the technique has been used successfully to improve the age control of e.g. peat deposits (e.g. Kilian et al. 1995; Speranza et al. 2000; Mauquoy et al. 2002; Blaauw et al. 2003) and lake sediments (Hormes et al. 2009; Snowball et al. 2010; Blaauw et al. 2011).

Annually laminated (varved) lake sediments can provide excellent information on paleoclimatic and paleoenvironmental conditions (e.g. Snowball et al. 2002; Ojala and Alenius 2005; Brauer et al. 2008). The formation of varved sediments requires special conditions, such as stratification of the water column and scarcity of oxygen in the bottom waters, which have been discussed by, amongst others, O'Sullivan (1983), Petterson (1996), and Zillén et al. (2003). In such cases, annual lamination counting can potentially provide very precise timescales that can be checked for accuracy and corrected by applying independent dating methods (e.g. Stanton et al. 2010; Bronk Ramsey et al. 2012). If the sediments are not continuously varved or if varves are difficult to identify, one has to resort to alternative methods, which is usually ${ }^{14} \mathrm{C}$ dating for the Holocene epoch. Some difficulties

\footnotetext{
${ }^{1}$ Department of Geology, Quaternary Sciences, Lund University, Sölvegatan 12, SE-223 62 Lund, Sweden. ${ }^{2}$ Corresponding author. Email: Anette.Mellstrom@geol.lu.se.

${ }^{3}$ Department of Earth Sciences - Geophysics, Uppsala University, Villavägen 16, SE-752 36 Uppsala, Sweden.
} 


\section{A Mellström et al.}

can arise when dating lake sediments with ${ }^{14} \mathrm{C}$. Terrestrial plant macrofossils are generally considered to yield ${ }^{14} \mathrm{C}$ age estimates closer to the real age of the sediment deposition than the bulk sediment samples (e.g. Törnqvist 1992; Björck et al. 1998). However, appropriate macrofossils may be scarce in the lake sediments and bulk sediments are often the only alternative. Bulk sediments, however, can be contaminated by older carbon that originates from various sources, which results in excessively old ages, i.e. an apparent inherited age, and a ${ }^{14} \mathrm{C}$ reservoir effect could be present (e.g. Olsson 1986; Björck and Wohlfarth 2001). This could be the case in areas of carbonate-rich bedrock or when old carbon from other sources, e.g. soil and vegetation, is remobilized from the catchment. The ${ }^{14} \mathrm{C}$ wiggle-match dating technique provides an opportunity to recognize and estimate the ${ }^{14} \mathrm{C}$ reservoir effect (Kilian et al. 1995). On the other hand, studies have shown that the lake reservoir effect can vary with time (e.g. Barnekow et al. 1998; Stanton et al. 2010), which may complicate the use of ${ }^{14} \mathrm{C}$ wiggle-matching. If the reservoir age varies drastically on a stratigraphic basis or if the inherited reservoir age is very large, the distinct shape of the ${ }^{14} \mathrm{C}$ calibration curve could be hard to recognize in a sequence of bulk ${ }^{14} \mathrm{C}$ dates.

${ }^{14} \mathrm{C}$ wiggle-matching has previously been applied to date bulk lake sediments with very good results (Snowball et al. 2010; Blaauw et al. 2011), but success is not guaranteed due to the aforementioned potential complications. In this study, the technique is applied to 15 bulk sediment samples dating to around 3000-2000 cal BP from Gyltigesjön, which is the southernmost lake in Sweden known to contain Holocene varves (Guhrén et al. 2003). An advantage of using annually laminated records is the opportunity to establish a chronology with precisely known age differences between the samples selected for ${ }^{14} \mathrm{C}$ analyses. Incorporation of known time increments and realistic counting error estimates in age models can narrow down the calibrated age ranges, thus refining the age determinations. We have chosen the period between 3000 and $2000 \mathrm{cal}$ BP for several reasons: (i) an increase in atmospheric ${ }^{14} \mathrm{C}$ at approximately $2800 \mathrm{cal}$ BP has been interpreted as a decrease in solar activity (e.g. van Geel et al. 1998; Speranza et al. 2000); (ii) several records indicate a change in climate (e.g. van Geel et al. 1996; Chambers et al. 2007; Plunkett and Swindles 2008; Martin-Puertas et al. 2012); and (iii) the geomagnetic field underwent prominent changes during this period (e.g. Snowball et al. 2007; Knudsen et al. 2008; Nilsson et al. 2011). In addition, the distinct shape of the ${ }^{14} \mathrm{C}$ calibration curve between 3000 and $2000 \mathrm{cal}$ BP facilitates the wiggle-matching approach. Therefore, we aimed to establish a high-resolution chronology for Gyltigesjön sediments, which can be applied to detailed paleomagnetic and paleoclimatic investigations. Moreover, we evaluate the ${ }^{14} \mathrm{C}$ wigglematch dating technique of bulk sediments with an unknown ${ }^{14} \mathrm{C}$ reservoir effect and estimate its variability. The chronology obtained, based on bulk sediments, is validated via ${ }^{14} \mathrm{C}$ dating of 3 plant macrofossils.

\section{SITE DESCRIPTION}

Gyltigesjön $\left(56^{\circ} 45^{\prime} 33^{\prime \prime} \mathrm{N}, 13^{\circ} 10^{\prime} 37^{\prime \prime} \mathrm{E}, 66 \mathrm{~m}\right.$ asl) is located in the province of Halland in southwest Sweden (Figure 1). The lake area covers $0.40 \mathrm{~km}^{2}$ and is a part of Simlångsdalen, a valley system with 4 lakes connected by the Fylleån River. Gyltigesjön is the northernmost lake and receives discharge from the Fylleån River, with the main inlet in the northern part of the lake and the outlet to the south. The southern basin of the lake is the deepest, with a maximum depth of nearly $20 \mathrm{~m}$. The catchment covers $182 \mathrm{~km}^{2}$ and is mostly covered by forest (61\%), followed by wetlands (25\%), open land (8\%), and water (6\%) (Guhrén et al. 2003). Augen granite and gneiss are the main bedrock types (Karlqvist et al. 1985) and the Quaternary deposits in the vicinity of the lake and main river inlet are primarily of glaciofluvial origin (Daniel 2006). 


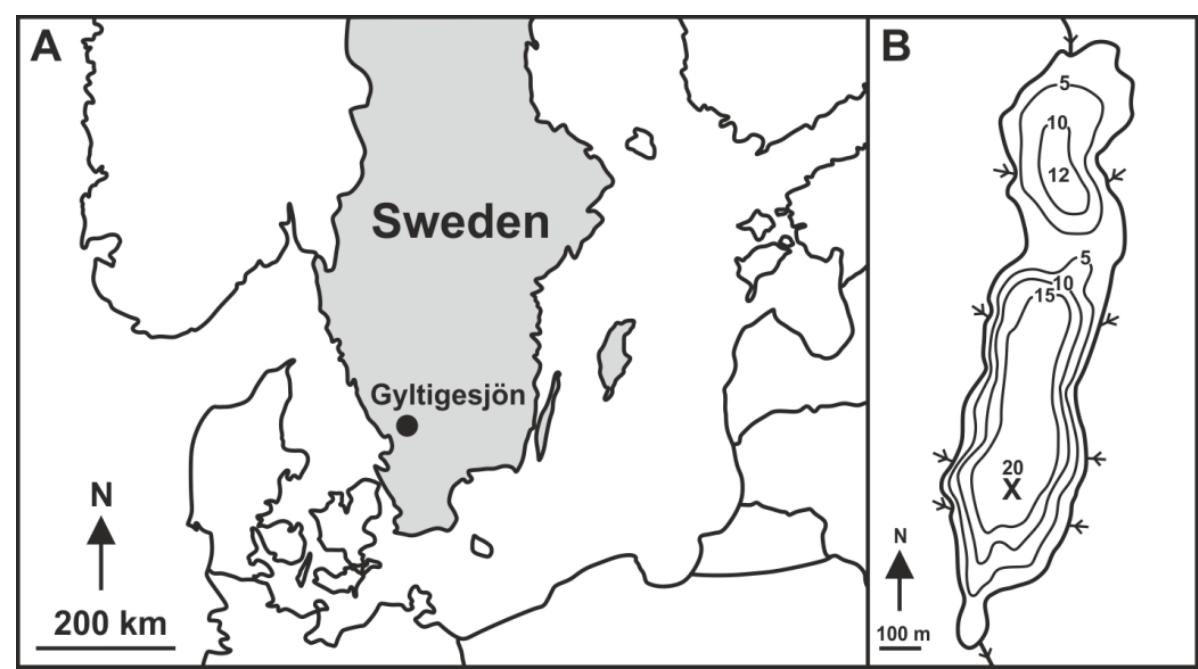

Figure 1 (A) Location map showing Gyltigesjön. (B) The lake basin (the numbers indicate the depth in m) with marked inflows, the outflow, and coring site (X).

\section{MATERIALS AND METHODS}

\section{Sediment Coring}

Two sediment sequences, GP1 and GP2, were recovered from the ice-covered lake surface in January 2010 with an additional sequence, GP4, in February 2011. Sampling was conducted from the deepest part of the lake, detected using a plumb-line and a hand-held echo-sounder. A modified rodoperated fixed-piston corer (Snowball and Sandgren 2002) was used to collect the sediments in cylindrical PVC tubes. Each of the GP1 and GP2 sequences contains about $5 \mathrm{~m}$ of sediment, divided into 4 core sections. These 2 sequences were cut into shorter sections at points to ensure that no sediments were lost. The complementary sequence, GP4, consists of about $5 \mathrm{~m}$ of sediment divided into $1-\mathrm{m}$ sections that also overlap with the GP1 and GP2 sediment sequences.

\section{Varve Characteristics}

Laminations in the uppermost sediments $(60-70 \mathrm{~cm})$ of Gyltigesjön were observed by Guhrén et al. (2003), who interpreted them as varves primarily based on their visual appearance. A parallel study indicates that these laminations extend to a sediment depth of $\sim 9 \mathrm{~m}$, which corresponds to an age of 8000 cal BP (I Snowball, unpublished data). Many lakes in Fennoscandia have varves with a clasticbiogenic composition with 3 to 4 laminae deposited per year that reflect climatically driven seasonal changes in sediment source (e.g. Renberg 1982; Petterson et al. 1993; Snowball et al. 1999; Ojala et al. 2000; Zillén et al. 2003). Mechanisms for differential lamina deposition include (i) river discharge during spring, which transports clastic-rich material from the catchment; (ii) increased biological production in the lake during the summer; and (iii) the deposition of homogeneous organic material when the lake surface is frozen during the winter and the least dense material can be deposited. An additional layer can be formed during autumn as a result of increased transportation of minerogenic material from the catchment after a prominent precipitation peak. In Gyltigesjön, the clastic spring lamina is less distinct compared to varved lakes located further north and northeast in Sweden (e.g. Snowball et al. 1999; Zillén et al. 2003). 


\section{A Mellström et al.}

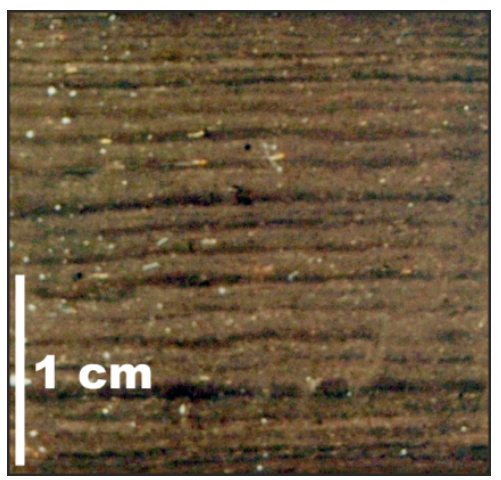

Figure 2 A 2.5 -cm section $(\sim 2550 \mathrm{cal} \mathrm{BP})$

showing typical varves in Gyltigesjön.

\section{Varve Chronology and Subsampling}

As a first step towards constructing a floating varve chronology, core correlations were necessary. A combination of data was used to correlate the sediment cores and to identify the period of interest. Visual stratigraphy (distinct patterns of laminations) and magnetic susceptibility were used to correlate the different core sections. Paleomagnetic data from Gyltigesjön (I Snowball, unpublished data) were compared to the paleomagnetic secular variation master curve for Fennoscandia (FENNOSTACK, Snowball et al. 2007) and distinct changes in inclination and declination allowed us, within the uncertainties of the paleomagnetic technique, to identify the period between $\sim 3000$ and 2000 cal BP.

To improve the visual appearance of the varves prior to varve counting, the sediment surface was carefully scraped parallel to the bedding plane with a razor blade. Pouring small amounts of water on to the sediment surface made the varves visually distinct, which simplified varve identification. Counting was performed independently by 2 investigators on a fresh sediment surface using a stereomicroscope (Wild Heerbrugg M8). Two core sections, GP1 and GP2 ( 125 cm each), were used for counting and a distinct marker varve identified in both cores ensured the exact correlation. Varve counting was divided into steps of $50 \mathrm{yr}$. Uncertain varves were counted as $0.5 \mathrm{yr}$ with an error of $\pm 0.5 \mathrm{yr}$ (e.g. Stanton et al. 2010), which is the methodology applied to the Greenland ice-core chronologies (e.g. Rasmussen et al. 2006). After counting 2 continuous sections of $20 \mathrm{yr}$ each, blocks of $10 \mathrm{yr}$ were counted and sampled for ${ }^{14} \mathrm{C}$ determinations ( 15 samples). Three macrofossils (fragments of oak leaves) were additionally found in GP4. Identification of crossover points between GP4 and the varve counting cores (GP1 and GP2) secured determination of age gaps between the bulk sediments and macrofossils. The investigated period encompasses 873 varves ( $\sim 1 \mathrm{~m}$ of sediment) and the counting error is estimated as approximately $4 \%$ (Table 1 ).

Table 1 Varve counting of the floating chronology and the estimated error.

\begin{tabular}{lc}
\hline Number of varves & Cumulative error $( \pm$ varves $)$ \\
\hline 100 & 6 \\
200 & 10 \\
300 & 15 \\
400 & 18 \\
500 & 21 \\
600 & 26 \\
700 & 29 \\
800 & 30 \\
873 & 34 \\
\hline
\end{tabular}


${ }^{14} \mathrm{C}$ Wiggle-Match Dating of Bulk Sediments

\section{Pretreatment, Graphitization, and AMS ${ }^{14} \mathrm{C}$ Dating}

Prior to ${ }^{14} \mathrm{C}$ dating, 3 steps were conducted: (i) removal of sample contaminants; (ii) combustion of the samples to $\mathrm{CO}_{2}$; and (iii) transformation of the $\mathrm{CO}_{2}$ into graphite that is used for accelerator mass spectrometry (AMS) measurement. To remove possible carbonate contamination, the bulk sediments were subjected to a pretreatment with $2 \% \mathrm{HCl}\left(80^{\circ} \mathrm{C}\right.$ overnight) and thereafter washed to neutral $\mathrm{pH}$ with deionized water before being dried. The fragile macrofossils were subjected to a less aggressive version of the standard acid-base-acid (ABA) method used to remove humic acids and modern $\mathrm{CO}_{2}$ that may have been absorbed. Some $0.25 \% \mathrm{NaOH}$ was added to the samples and heated $\left(60^{\circ} \mathrm{C}, 50 \mathrm{~min}\right)$ with a subsequent wash to neutral $\mathrm{pH}$ before treatment with $1 \% \mathrm{HCl}\left(80^{\circ} \mathrm{C}\right.$, $50 \mathrm{~min}$ ). In a last step, the samples were once again washed with deionized water and dried.

Combustion of the samples to $\mathrm{CO}_{2}$ was implemented in sealed glass tubes using $\mathrm{CuO}$ for oxidation. Following combustion, graphitization was performed using a semi-automated graphitization line (Unkel 2006). Fe powder was used as a catalyst for the graphitization, having been cleaned through conditioning. Thereafter, the $\mathrm{CO}_{2}$ was reduced to graphite by adding $\mathrm{H}_{2}$ and heating to $600{ }^{\circ} \mathrm{C}$. Finally, the graphite was pressed into targets and stored in Ar-filled tubes prior to measurement at the Single Stage AMS (SSAMS) facility at Lund University. Evaluation and corrections of the AMS data were performed using Bats software (Wacker et al. 2010).

\section{${ }^{14} \mathrm{C}$ Wiggle-Match Dating}

The period around 3000-2000 cal BP is characterized by 2 abrupt increases in the atmospheric ${ }^{14} \mathrm{C}$ concentration, at 2800-2680 and 2370-2290 cal BP, respectively. These increases correspond to steep drops in the ${ }^{14} \mathrm{C}$ age versus calendar age relationship (Reimer et al. 2009). In between these peaks, there is a $\sim 300$-yr-long ${ }^{14} \mathrm{C}$ age plateau. Thus, this period demonstrates a suitable shape in the calibration curve for optimal ${ }^{14} \mathrm{C}$ wiggle-match modeling (e.g. Figure 3).

The curve-fitting process of matching ${ }^{14} \mathrm{C}$ ages to the ${ }^{14} \mathrm{C}$ calibration curve can be performed using various approaches (see e.g. Blaauw et al. 2003). Bayesian methods are commonly used and userfriendly routines are incorporated in ${ }^{14} \mathrm{C}$ calibration software, such as OxCal (Bronk Ramsey 1995, 2009a), Bpeat (Blaauw and Christen 2005), and Bacon (Blaauw and Christen 2011). Simple correlation analysis between ${ }^{14} \mathrm{C}$ variations in the sediment and the calibration record can, however, lead to similar results (Snowball et al. 2010). Here, we used the calibration program OxCal v 4.1 (Bronk Ramsey 2009a) with the IntCal09 ${ }^{14} \mathrm{C}$ calibration curve (Reimer et al. 2009) and implemented the V_Sequence depositional model, which considers age differences and relative dating uncertainties between samples (Bronk Ramsey 2008). This model also provides an agreement index that is designed to assess the quality of the age model. For a robust age model, the agreement index should be above $60 \%$ (Bronk Ramsey 2009a).

\section{RESULTS}

\section{Wiggle-Match Dating of Bulk Sediments}

The dates of the 15 bulk sediment samples are compiled in Table 2. Figure 3 shows that the results of the ${ }^{14} \mathrm{C}$ bulk sediment measurements do not match with the distinct wiggles in the ${ }^{14} \mathrm{C}$ calibration curve without correction for a reservoir offset. In addition, the calculated agreement index (for the sequence as a whole) is remarkably low, only $1.9 \%$.

The poor match could indicate that ${ }^{14} \mathrm{C}$-depleted material influences the sediments in Gyltigesjön, i.e. the measured samples do not directly reflect the atmospheric ${ }^{14} \mathrm{C}$ concentration at the time of 


\section{A Mellström et al.}

Table $2{ }^{14} \mathrm{C}$ dating results of the bulk sediments from Gyltigesjön, placed on the composite depth scale according to I Snowball (unpublished data). The varve ages are relative to the oldest sample (LuC-45.1.1) and rounded to integer values (since the counting method can produce non-integer values). The errors are also rounded up to the next integer value.

\begin{tabular}{lllll}
\hline LuC- $\mathrm{nr}$ & Sediment core & Composite depth $(\mathrm{cm})$ & Relative varve age & ${ }^{14} \mathrm{C}$ BP \\
\hline 31.1 .1 & GP1 & 448 & $694 \pm 27$ & $2477 \pm 45$ \\
32.1 .1 & GP1 & 452 & $644 \pm 23$ & $2516 \pm 45$ \\
33.1 .1 & GP1 & 457 & $594 \pm 20$ & $2572 \pm 45$ \\
34.1 .1 & GP1 & 462 & $544 \pm 18$ & $2786 \pm 75$ \\
35.1 .1 & GP1 & 470 & $495 \pm 16$ & $2771 \pm 45$ \\
36.1 .1 & GP1 & 478 & $444 \pm 15$ & $2853 \pm 70$ \\
37.1 .1 & GP1 & 483 & $395 \pm 13$ & $2666 \pm 35$ \\
38.1 .1 & GP1 & 490 & $347 \pm 11$ & $2683 \pm 60$ \\
39.1 .1 & GP1 & 495 & $297 \pm 10$ & $2858 \pm 45$ \\
40.1 .1 & GP1 & 500 & $248 \pm 8$ & $2855 \pm 70$ \\
41.1 .1 & GP1 & 506 & $198 \pm 6$ & $2955 \pm 45$ \\
42.1 .1 & GP1 & 510 & $150 \pm 4$ & $2941 \pm 60$ \\
43.1 .1 & GP2 & 517 & $99 \pm 4$ & $3095 \pm 45$ \\
44.1 .1 & GP2 & 522 & $49 \pm 3$ & $3095 \pm 45$ \\
45.1 .1 & GP2 & 527 & $0 \pm 0$ & $3209 \pm 45$ \\
\hline
\end{tabular}

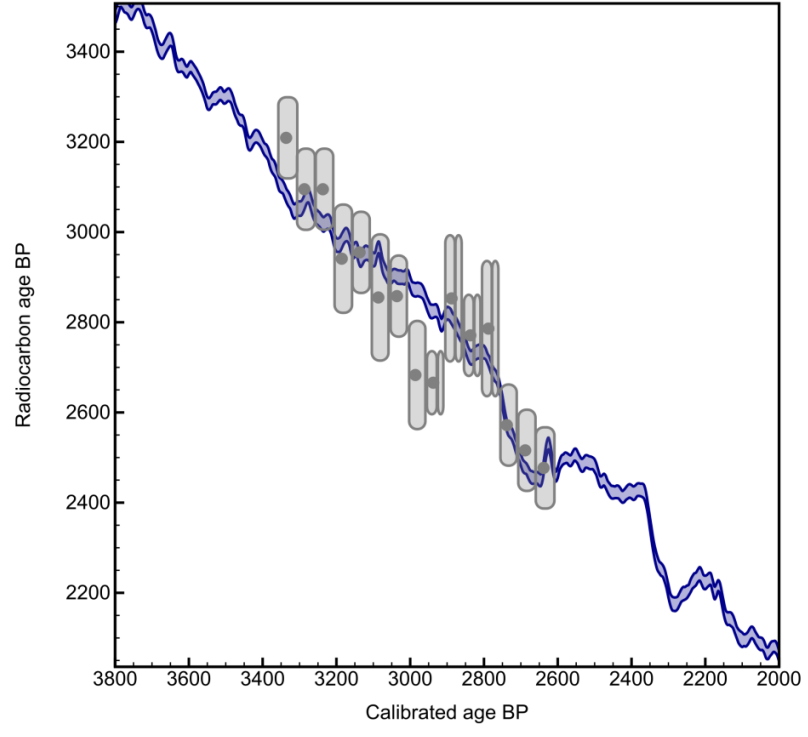

Figure 3 Age model produced by OxCal v 4.1 (Bronk Ramsey 2009a) using the V_Sequence depositional model (Bronk Ramsey 2008) with the IntCal09 ${ }^{14} \mathrm{C}$ calibration curve (Reimer et al. 2009). The results include 15 bulk sediment samples with the assumption that no ${ }^{14} \mathrm{C}$ reservoir effect is present. The calibrated ages are shown with the $95.4 \%$ highest probability density ranges and mean ages are indicated by solid circles.

sediment deposition. Therefore, the effect of this ${ }^{14} \mathrm{C}$-depleted material needs to be assessed. We followed the approach of Snowball et al. (2010) and ran V_Sequence age models with subtracted ${ }^{14} \mathrm{C}$ reservoir ages from 0 to $1000 \mathrm{yr}$ at 10 -yr intervals, using the agreement index $\left(\mathrm{A}_{\text {model }}\right)$ to evaluate the quality of the age model (Figure 4). Variations in the agreement index show that alternative age models, which consider old carbon influences, agree much better with the ${ }^{14} \mathrm{C}$ calibration record. The highest agreement indices are found with a subtracted ${ }^{14} \mathrm{C}$ reservoir age of $\sim 250 \mathrm{yr}$ and the corresponding age model is shown in Figure 5. However, the obtained agreement index $\left(\mathrm{A}_{\text {model }}\right)$ is considerably below the limit of $60 \%$, and several samples had lower values than acceptable. An outlier analysis was therefore applied to this age model using the r-type, which considers some variation in 
the ${ }^{14} \mathrm{C}$ concentration, and the prior probability of being an outlier was set to 0.05 (Bronk Ramsey 2009b; Bronk Ramsey et al. 2010). With this method, no outliers were indicated. The most likely explanation for the low agreement indices is that the samples have differing reservoir ages (i.e. the contribution of old carbon varies between samples); therefore, the straightforward method of inferring 1 reservoir age for all samples might be too simplistic. The agreement index can be increased by accounting for these variable reservoir offsets (see next section).

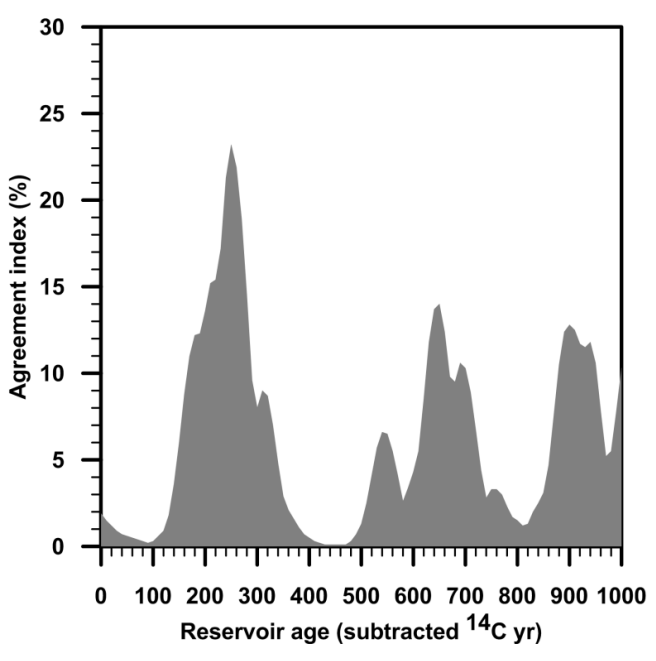

Figure 4 Agreement indices $\left(\mathrm{A}_{\text {model }}\right)$ derived from the V_Sequence depositional model (Bronk Ramsey 2008) by subtracting assumed ${ }^{14} \mathrm{C}$ reservoir ages from the measured values $(0-1000 \mathrm{yr})$. The optimal agreement is obtained with a subtracted reservoir age of $250 \mathrm{yr}$.

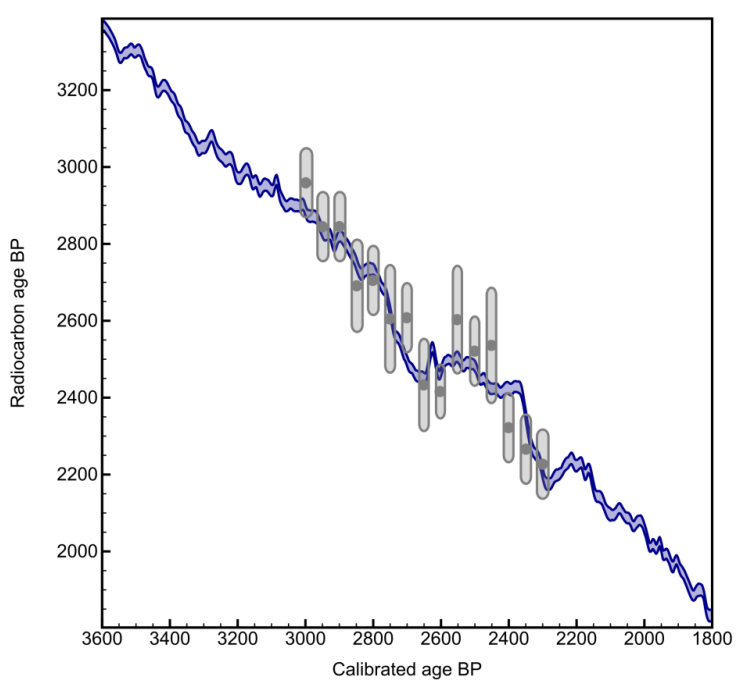

Figure 5 The V Sequence age model using 15 bulk sediment samples and a ${ }^{14} \mathrm{C}$ reservoir age of $250 \mathrm{yr}$ subtracted from each sample.

\section{Estimating the Variability in the Inferred Reservoir Age}

There are differences between the reservoir-corrected ${ }^{14} \mathrm{C}$ ages for the samples and the corresponding ${ }^{14} \mathrm{C}$ ages of the calibration curve (Figure 5 , note that the $95.4 \%$ highest probability density range is shown). To assess the variability in reservoir ages, we used the best wiggle-match dating results (250 yr subtracted from the ${ }^{14} \mathrm{C}$ ages) to estimate the age offset for each ${ }^{14} \mathrm{C}$ sample. For the mean age of each calibrated ${ }^{14} \mathrm{C}$ sample, the difference between the reservoir-corrected ${ }^{14} \mathrm{C}$ age of the sample and the corresponding ${ }^{14} \mathrm{C}$ age of the calibration curve was calculated. Error estimation $(1 \sigma)$ was based on errors associated both with the ${ }^{14} \mathrm{C}$ measurement and the error of the ${ }^{14} \mathrm{C}$ calibration curve. According to these calculations, $53 \%$ of the samples lie within the error estimate and no age-depth related trend is detected (Figure 6). Nevertheless, Figure 6 also suggests that the error $\left({ }^{14} \mathrm{C}\right.$ measurement and ${ }^{14} \mathrm{C}$ calibration curve) is underestimating the real uncertainty. In an effort to alternatively assess a realistic total error, which also includes uncertainties in the reservoir age, the standard deviation between reservoir-corrected ${ }^{14} \mathrm{C}$ ages and the corresponding ${ }^{14} \mathrm{C}$ ages of the calibration curve was calculated. The resulting standard deviation is $68 \mathrm{yr}$ and this value was used in the V_Sequence age model and leads to satisfactory agreement indices for ${ }^{14} \mathrm{C}$ reservoir ages of $240-280 \mathrm{yr}$, with the highest agreement at $260 \mathrm{yr}$ (Figure 7). 


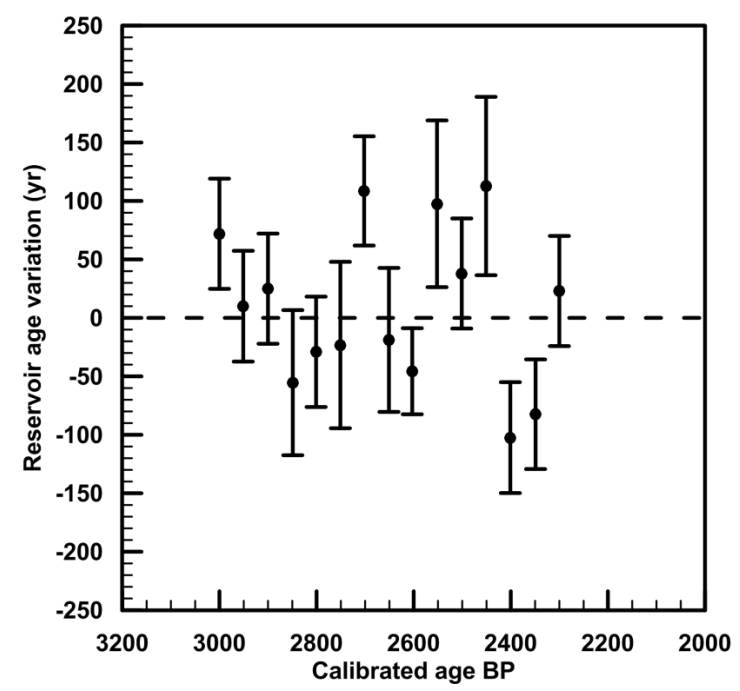

Figure 6 Deviations between reservoir-corrected ${ }^{14} \mathrm{C}$ ages and the corresponding ${ }^{14} \mathrm{C}$ ages of the calibration curve using the best age model. Error bars show combined error of ${ }^{14} \mathrm{C}$ measurement and the ${ }^{14} \mathrm{C}$ calibration curve $(1 \sigma)$.

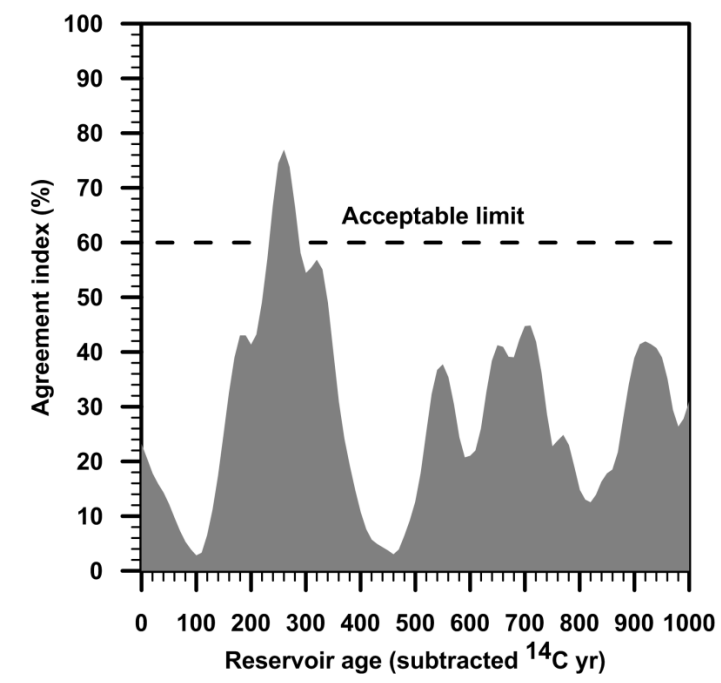

Figure 7 Agreement indices $\left(\mathrm{A}_{\text {model }}\right)$ for bulk sediments when sample reservoir age variations are taken into account. Assumed ${ }^{14} \mathrm{C}$ reservoir ages are subtracted from the measured values (0-1000 yr). The best-fitting age model is obtained with a reservoir age of $260 \mathrm{yr}$.

In an iterative process, it is possible to determine a new reservoir age uncertainty with the slightly revised results. The results shown in Figure 7 lead to a reservoir age estimate that is very similar to the results shown in Figure 4. Therefore, in our case this process does not improve the age model. 


\section{Testing the Result with ${ }^{14} \mathrm{C}$ Dating of Macrofossils}

Dating results of the macrofossils are shown in Table $3 .{ }^{14} \mathrm{C}$ measurements of leaves are expected to reflect the ${ }^{14} \mathrm{C}$ signal of the atmosphere during the season of growth. A significant delay between leaf drop and incorporation of well-preserved leaf fragments in the sediment is not expected. Therefore, the macrofossils can be used to cross-validate the age model obtained.

Table 3 Dating results of the macrofossils (fragments of oak leaves). The varve ages are relative to the oldest bulk sediment sample (LuC-45.1.1, see Table 2). A relative varve age error of $5 \mathrm{yr}$ is added to the youngest sample due to a correlation uncertainty.

\begin{tabular}{lllll}
\hline LuC- $\mathrm{nr}$ & Sediment core & Composite depth $(\mathrm{cm})$ & Relative varve age & ${ }^{14} \mathrm{C} \mathrm{BP}$ \\
\hline 49.1 .1 & GP4 & 420 & $868 \pm 39$ & $2094 \pm 40$ \\
50.1 .1 & GP4 & 512 & $134 \pm 4$ & $2793 \pm 40$ \\
51.1 .1 & GP4 & 521 & $57 \pm 3$ & $2812 \pm 40$ \\
\hline
\end{tabular}

The ${ }^{14} \mathrm{C}$ dates of oak leaves were included in the V_Sequence depositional model, along with the bulk sediment samples, to investigate how well they fitted into the age models with different ${ }^{14} \mathrm{C}$ reservoir ages. We repeated the V_Sequence procedure applied to produce the previous age models and subtracted ${ }^{14} \mathrm{C}$ reservoir ages (for the bulk sediments) from 0 to $550 \mathrm{yr}$ at 10 -yr intervals (note that no ${ }^{14} \mathrm{C}$ ages were subtracted from the macrofossil dates). For the bulk sediments, the sample reservoir age variations are taken into account (see preceding section, Figure 6). The results are similar to those obtained from the model based solely on bulk sediment samples (see Figure 7), with the exception for larger reservoir ages where the agreement indices show values around 0 . The highest agreement index is obtained with a reservoir age of 260 yr. Figure 8 shows the resulting final age model (OxCal coding is given in the Supplementary file with the online version of this article).

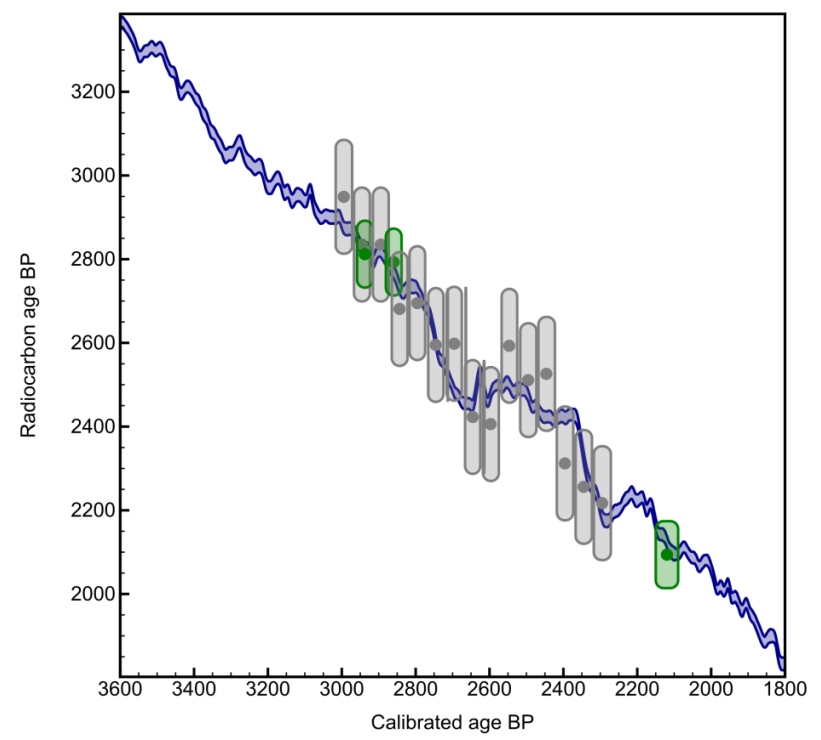

Figure 8 Final age model including 15 bulk sediment samples $\left({ }^{14} \mathrm{C}\right.$ reservoir age of $260 \mathrm{yr}$ ) and 3 macrofossil samples (in green, with no ${ }^{14} \mathrm{C}$ reservoir age). 


\section{A Mellström et al.}

Finally, we compare 3 age-depth models to investigate the consistency between them (Figure 9). The first model is based on the macrofossils only, calibrated with a V_Sequence depositional model (Figure 9, solid lines). The second is based solely on bulk sediments $\left({ }^{14} \mathrm{C}\right.$ reservoir age correction of $260 \mathrm{yr}$ ) and sample reservoir age variations taken into account (Figure 9, purple shading). The third model is obtained from the final age model, which includes both bulk sediment and macrofossils (Figure 9, dashed lines). Only minor differences exist between the age-depth model exclusively based on bulk sediment measurements and when, in addition, macrofossils are included. Calibrated age ranges $(95.4 \%$ highest probability density range) are largest for the age model based on the 3 macrofossil measurements ( $\sim 115-130 \mathrm{yr})$, and smaller for the bulk sediment dates $(\sim 60-65 \mathrm{yr})$ and when both bulk sediments and macrofossil results are included ( $45-60 \mathrm{yr})$.

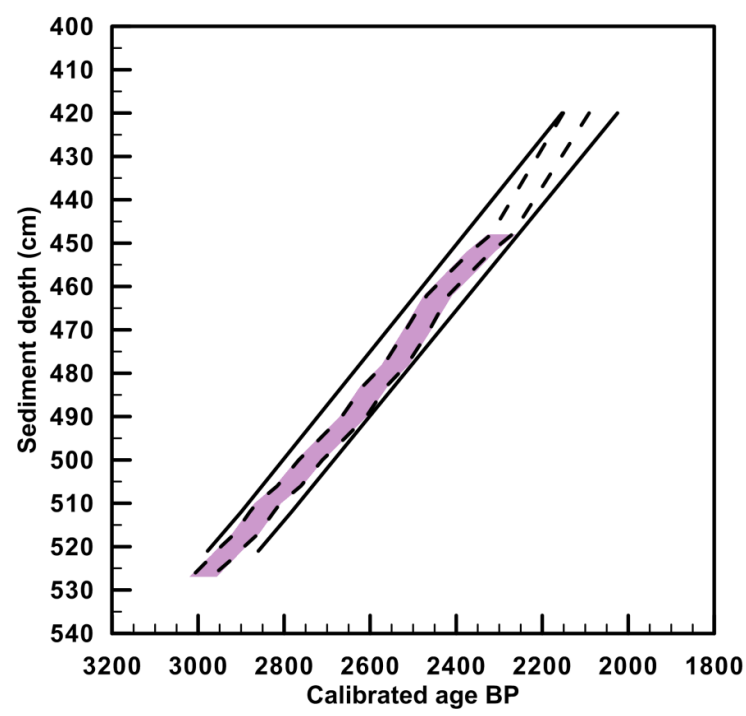

Figure 9 Summary of the different age-depth models based on macrofossils only (solid lines), bulk sediments only $\left({ }^{14} \mathrm{C}\right.$ reservoir age of $260 \mathrm{yr}$ ) (purple shading), and bulk sediments $\left({ }^{14} \mathrm{C}\right.$ reservoir age of $260 \mathrm{yr}$ ) combined with macrofossils (dashed lines). The ages comprise the $95.4 \%$ highest probability density range.

\section{DISCUSSION}

Several important aspects need to be addressed to evaluate the accuracy and precision of the constructed chronology. These include counting errors, uncertainties associated with the ${ }^{14} \mathrm{C}$ reservoir effect, and age model validation with macrofossil ${ }^{14} \mathrm{C}$ dates.

\section{Counting Errors}

There are inevitable uncertainties associated with the construction of a varve chronology. Such uncertainties include, missing varves, sediment disturbances, and problems with unequivocal identification of the varves (Ojala et al. 2012). However, the age models based on bulk sediments were produced using the V_Sequence depositional model, which allows for inclusion of varve counting uncertainties. Since the varve counting method produces non-integer values, the errors used in the model were rounded up to the next integer. This means that the results lead to rather conservatively estimated errors. In addition, the age estimates remain similar even if the varve counting errors would be twice as large compared to the estimated errors. 


\section{${ }^{14} \mathrm{C}$ Wiggle-Match Dating of Bulk Sediments}

\section{${ }^{14} \mathrm{C}$ Reservoir Effect}

The ${ }^{14} \mathrm{C}$ dates provided by the AMS measurements reflect the age of the dated fraction. Bulk samples contain a mixture of sediments from different sources and a ${ }^{14} \mathrm{C}$ reservoir effect can be expected. Changes in the lake and its catchment might alter the composition of the sediment and thereby induce variations in the reservoir age. Several sources for this old carbon input are possible. If the bedrock is rich in carbonates, a hardwater effect might be present where the ${ }^{14} \mathrm{C}$ is diluted by dissolved carbonates (Deevey et al. 1954; Andree et al. 1986; Olsson 1991). Dissolved inorganic carbon can be transported to the lake by groundwater and old organic material can be brought in from the catchment (e.g. Björck and Wohlfarth 2001). The bedrock around Gyltigesjön is dominated by granite and gneiss and a significant hardwater effect is not expected. However, remobilization of older carbon in the catchment (e.g. soil derived carbon) and in the lake probably causes the observed reservoir effect.

Before fully applying the ${ }^{14} \mathrm{C}$ wiggle-match dating technique, it is advisable to first test the method with a few samples - both to identify the amplitude of reservoir age changes and to pinpoint the period of interest. In our case, wiggle-match dating yielded good results because the reservoir effect appears to be relatively small and constant.

\section{${ }^{14} \mathrm{C}$ Reservoir Ages in Gyltigesjön}

The Bayesian method applied to estimate the ${ }^{14} \mathrm{C}$ reservoir age with wiggle-matching proved successful for Gyltigesjön sediments. However, the interpretation is not straightforward. The highest agreement index for the bulk sediment ${ }^{14} \mathrm{C}$ results is reached with a reservoir age of $250{ }^{14} \mathrm{C}$ yr, yet other reservoir ages also produced relatively high agreement indices. Three additional peaks exist around 540, 650, and 900 subtracted ${ }^{14} \mathrm{C}$ yr (Figure 4). With prior knowledge about approximate sediment ages through relative dating with paleomagnetic secular variation data, we can argue that reservoir ages of $\sim 900 \mathrm{yr}$ would produce unrealistic age models, and even without the additional macrofossils results we can disregard them. If the ${ }^{14} \mathrm{C}$ reservoir effect is assumed to be $\sim 540 \mathrm{yr}$ (second peak in agreement indices), then the paleomagnetic record of Gyltigesjön would show slightly younger geomagnetic field features than previously reported (e.g. Snowball et al. 2007). In addition, the 3 dated macrofossils show no support for ${ }^{14} \mathrm{C}$ reservoir ages around $540 \mathrm{yr}$. Instead, we focus on reservoir ages around $250{ }^{14} \mathrm{C} \mathrm{yr}$, which showed the best agreement for the age model.

Calculations of sample reservoir age variations (assuming an average reservoir age of $250{ }^{14} \mathrm{C} \mathrm{yr}$ ) revealed that the majority of the samples are within the error estimates (Figure 6). However, $47 \%$ of the samples fall outside the $1 \sigma$ error range (more than statistically expected). One can speculate that changes in climate might be a source for deviations from the average reservoir age, through shifts in the cycling of carbon in the lake and its catchment. In any case, no systematic age trend was found. Another important aspect is the possibility of outliers. Undetected outliers or other unaccounted errors associated with the ${ }^{14} \mathrm{C}$ dates may lead to a different estimate of the reservoir age. By visual inspection, we have no evidence for clear outliers. Outliers can also be detected with the agreement index, or with an outlier analysis (Bronk Ramsey 2009b). Model runs with different ${ }^{14} \mathrm{C}$ reservoir ages lead to different suggestions for outliers when using the agreement index approach. Therefore, an outlier analysis was applied to the best age model with a subtracted reservoir age of $250{ }^{14} \mathrm{C} \mathrm{yr}$. Since ${ }^{14} \mathrm{C}$ reservoir age variations could be expected, the r-type was used (Bronk Ramsey 2009b; Bronk Ramsey et al. 2010). However, no outliers were indicated with this method. By allowing for additional uncertainties in the reservoir age estimate (Figure 6), good agreement indices (above $60 \%$ ) are achieved for ${ }^{14} \mathrm{C}$ reservoir ages of $240-280 \mathrm{yr}$ with the highest agreement at $260 \mathrm{yr}$. 


\section{A Mellström et al.}

\section{Validation with Macrofossils Dating}

Three macrofossils were ${ }^{14} \mathrm{C}$ dated to cross-validate the obtained age model. Correlation uncertainties between core sections were accounted for by increasing the corresponding errors of the relative age determinations. The fragments of leaves are assumed to reflect the atmospheric ${ }^{14} \mathrm{C}$ concentration at the time of their growth, and that they were deposited shortly after leaf drop without being redeposited at a significantly later point in time. Since the macrofossil ${ }^{14} \mathrm{C}$ results fit very well into the preferred age model inferred from the bulk sediment measurements that were corrected by subtracting $260{ }^{14} \mathrm{C}$ yr, there is no reason to question their reliability. By including the ${ }^{14} \mathrm{C}$ ages of the macrofossils in the age model, the highest agreement index was again obtained with a ${ }^{14} \mathrm{C}$ reservoir age of $260 \mathrm{yr}$. The combined bulk sediment and macrofossil age model therefore provides support for the previous model based on bulk sediment results only.

Three different age-depth models were established to assess the calibrated age uncertainties associated with the ${ }^{14} \mathrm{C}$ wiggle-matching of bulk ${ }^{14} \mathrm{C}$ measurements (Figure 9). With the ${ }^{14} \mathrm{C}$ wiggle-match technique, the calibrated age uncertainties are substantially reduced compared to only ${ }^{14} \mathrm{C}$ calibration of the 3 macrofossil results. The age-depth model based solely on bulk sediment measurements is similar to the model with both bulk sediment and macrofossil results included. Such similarity confirms the possibility to construct accurate chronologies without including macrofossils.

\section{CONCLUSIONS}

${ }^{14} \mathrm{C}$ wiggle-matching of bulk sediment ${ }^{14} \mathrm{C}$ measurements was successfully applied to produce a geochronology for Gyltigesjön sediments deposited between $\sim 3000$ and 2000 cal BP with relatively small age uncertainties. The method provided an opportunity to estimate the ${ }^{14} \mathrm{C}$ reservoir age as $\sim 260$ yr. The chronology was confirmed with ${ }^{14} \mathrm{C}$ dating of additional macrofossils. The results indicate that, at least in settings similar to Gyltigesjön, it is possible to date bulk sediments with the ${ }^{14} \mathrm{C}$ wiggle-match dating technique and to obtain age-depth relationships with relatively small errors. Therefore, ${ }^{14} \mathrm{C}$ wiggle-matching can be an alternative to and/or be complementary when constructing very accurate chronologies, even when macrofossils are scarcely distributed or absent in the sediments. The age model established here can be utilized for detailed investigations of environmental proxies with the additional advantage that their timing with respect to solar forcing changes is very well determined as these are also seen in the ${ }^{14} \mathrm{C}$ wiggles.

\section{ACKNOWLEDGMENTS}

The study was supported by the Swedish Research Council through a Linnaeus grant to Lund University (LUCCI) and project grants to Ian Snowball (dossier nr 2008-7118 and 2011-3353). Raimund Muscheler is supported by the Royal Swedish Academy of Sciences through a grant financed by the Knut and Alice Wallenberg Foundation. We would like to thank Florian Adolphi for AMS measurements, data evaluation, and discussions, and Göran Skog for discussions regarding AMS. Thanks also to Emelie Ahlstrand, Andreas Nilsson, and Per Sandgren for lake coring assistance and Stefanie Müller for sample preparation assistance. We also thank an anonymous reviewer for providing helpful and constructive comments.

\section{REFERENCES}

Andree M, Oeschger H, Siegenthaler U, Riesen T, Moell M, Ammann B, Tobolski K. 1986. ${ }^{14} \mathrm{C}$ dating of plant macrofossils in lake sediment. Radiocarbon 28(2A): 411-6.

Barnekow L, Possnert G, Sandgren P. 1998. AMS ${ }^{14} \mathrm{C}$ chronologies of Holocene lake sediments in the Abisko area, northern Sweden - a comparison between dated bulk sediment and macrofossil samples. GFF 120(1):59-67.

Björck S, Wohlfarth B. 2001. ${ }^{14} \mathrm{C}$ chronostratigraphic 


\section{${ }^{14} \mathrm{C}$ Wiggle-Match Dating of Bulk Sediments}

techniques in paleolimnology. In: Last WM, Smol JP, editors. Tracking Environmental Change Using Lake Sediments. p 204-44.

Björck S, Bennike O, Possnert G, Wohlfarth B, Digerfeldt G. 1998. A high-resolution ${ }^{14} \mathrm{C}$ dated sediment sequence from southwest Sweden: age comparisons between different components of the sediment. Journal of Quaternary Science 13(1):85-9.

Blaauw M, Christen JA. 2005. Radiocarbon peat chronologies and environmental change. Applied Statistics 54(4):805-16.

Blaauw M, Christen JA. 2011. Flexible paleoclimate agedepth models using an autoregressive gamma process Bayesian Analysis 6(3):457-74.

Blaauw M, Heuvelink GBM, Mauquoy D, van der Plicht $\mathrm{J}$, van Geel B. 2003. A numerical approach to ${ }^{14} \mathrm{C}$ wiggle-match dating of organic deposits: best fits and confidence intervals. Quaternary Science Reviews 22(14): 1485-500.

Blaauw M, van Geel B, van der Plicht J. 2004. Solar forcing of climatic change during the mid-Holocene: indications from raised bogs in the Netherlands. The Holocene 14(1):35-44.

Blaauw M, van Geel B, Kristen I, Plessen B, Lyaruu A, Engstrom DR, van der Plicht J, Verschuren D. 2011 High-resolution ${ }^{14} \mathrm{C}$ dating of a 25,000-year lake-sediment record from equatorial East Africa. Quaternary Science Reviews 30(21-22):3043-59.

Brauer A, Haug GH, Dulski P, Sigman DM, Negendank JFW. 2008. An abrupt wind shift in western Europe at the onset of the Younger Dryas cold period. Nature Geoscience 1:520-3.

Bronk Ramsey C. 1995. Radiocarbon calibration and analysis of stratigraphy: the OxCal program. Radiocarbon 37(2):425-30.

Bronk Ramsey C. 2008. Deposition models for chronological records. Quaternary Science Reviews 27(1-2): $42-60$.

Bronk Ramsey C. 2009a. Bayesian analysis of radiocarbon dates. Radiocarbon 51(1):337-60.

Bronk Ramsey C. 2009b. Dealing with outliers and offsets in radiocarbon dating. Radiocarbon 51(3):102345

Bronk Ramsey C, Dee M, Lee S, Nakagawa T, Staff RA. 2010. Developments in the calibration and modeling of radiocarbon dates. Radiocarbon 52(2-3):953-61.

Bronk Ramsey C, Staff RA, Bryant CL, Brock F, Kitagawa $\mathrm{H}$, van der Plicht J, Schlolaut G, Marshall MH, Brauer A, Lamb HF, Payne RL, Tarasov PE, Haraguchi T, Gotanda K, Yonenobu H, Yokoyama Y, Tada R, Nakagawa T. 2012. A complete terrestrial radiocarbon record for 11.2 to $52.8 \mathrm{kyr}$ B.P. Science 338(6105): $370-4$

Chambers FM, Mauquoy D, Brain SA, Blaauw M, Daniell JRG. 2007. Globally synchronous climate change 2800 years ago: proxy data from peat in South America. Earth and Planetary Science Letters 253(34):439-44.
Daniel E. 2006. Jordartskartan 4C Halmstad NO. Sveriges geologiska undersökning $\mathrm{K} 58$

Deevey ES, Gross MS, Hutchinson GE, Kraybill HL. 1954. The natural $\mathrm{C}^{14}$ contents of materials from hardwater lakes. Proceedings of the National Academy of Sciences 40:285-8.

Guhrén M, Bindler R, Korsman T, Rosén P, Wallin J-E, Renberg I. 2003. Paleolimnologiska undersökningar av kalkade referenssjöar. Del. 4. Bösjön (Dalarnas län), Gyltigesjön (Hallands län) och Långsjön (Örebro län). Umeå: Institutionen för ekologi och geovetenskap, Umeå Universitet. p 37.

Hormes A, Blaauw M, Dahl SO, Nesje A, Possnert G. 2009. Radiocarbon wiggle-match dating of proglacial lake sediments - implications for the $8.2 \mathrm{ka}$ event. Quaternary Geochronology 4(4):267-77.

Karlén W, Kuylenstierna J. 1996. On solar forcing of Holocene climate: evidence from Scandinavia. The $\mathrm{Ho}$ locene 6(3):359-65.

Karlqvist L, de Geer J, Fogdestam B, Engqvist P. 1985. Beskrivning och bilagor till hydrogeologiska kartan över Hallands län. Sveriges geologiska undersökning Ah 8

Kilian MR, van der Plicht J, van Geel B. 1995. Dating raised bogs: new aspects of AMS ${ }^{14} \mathrm{C}$ wiggle matching, a reservoir effect and climatic change. Quaternary Science Reviews 14(10):959-66.

Knudsen MF, Riisager P, Donadini F, Snowball I, Muscheler R, Korhonen K, Pesonen LJ. 2008. Variations in the geomagnetic dipole moment during the Holocene and the past $50 \mathrm{kyr}$. Earth and Planetary Science Letters 272(1-2):319-29.

Martin-Puertas C, Matthes K, Brauer A, Muscheler R, Hansen F, Petrick C, Aldahan A, Possnert G, van Geel B. 2012. Regional atmospheric circulation shifts induced by a grand solar minimum. Nature Geoscience 5:397-401.

Mauquoy D, van Geel B, Blaauw M, van der Plicht J. 2002. Evidence from northwest European bogs shows 'Little Ice Age' climatic changes driven by variations in solar activity. The Holocene 12(1):1-6.

Nilsson A, Muscheler R, Snowball I. 2011. Millennial scale cyclicity in the geodynamo inferred from a dipole tilt reconstruction. Earth and Planetary Science Letters 311(3-4):299-305.

Ojala AEK, Alenius T. 2005. 10000 years of interannual sedimentation recorded in the Lake Nautajärvi (Finland) clastic-organic varves. Palaeogeography, Palaeoclimatology, Palaeoecology 219(3-4):285302.

Ojala AEK, Saarinen T, Salonen V-P. 2000. Preconditions for the formation of annually laminated lake sediments in southern and central Finland. Boreal Environment Research 5:243-55.

Ojala AEK, Francus P, Zolitschka B, Besonen M, Lamoureux SF. 2012. Characteristics of sedimentary varve chronologies - a review. Quaternary Science Reviews 43:45-60. 


\section{A Mellström et al.}

Olsson IU. 1986. Radiometric dating. In: Berglund BE, editor. Handbook of Holocene Palaeoecology and Palaeohydrology. Chichester: John Wiley \& Sons Ltd. p 273-312.

Olsson IU. 1991. Accuracy and precision in sediment chronology. Hydrobiologia 214:25-34.

O'Sullivan PE. 1983. Annually-laminated lake sediments and the study of Quaternary environmental changes - a review. Quaternary Science Reviews 1(4): 245-313.

Pearson GW. 1986. Precise calendrical dating of known growth-period samples using a 'curve fitting' technique. Radiocarbon 28(2A):292-9.

Petterson G. 1996. Varved sediments in Sweden: a brief review. In: Kemp AES, editor. Palaeoclimatology and Palaeoceanography from Laminated Sediments. Geological Society of London. p 73-7.

Petterson G, Renberg I, Geladi P, Lindberg A, Lindgren F. 1993. Spatial uniformity of sediment accumulation in varved lake sediments in northern Sweden. Journal of Paleolimnology 9(3):195-208.

Plunkett G, Swindles GT. 2008. Determining the Sun's influence on Lateglacial and Holocene climates: a focus on climate response to centennial-scale solar forcing at 2800 cal. BP. Quaternary Science Reviews 27(1-2):175-84.

Rasmussen SO, Andersen KK, Svensson AM, Steffensen JP, Vinther BM, Clausen HB, Siggaard-Andersen ML, Johnsen SJ, Larsen LB, Dahl-Jensen D, Bigler M, Röthlisberger R, Fischer H, Goto-Azuma K, Hansson ME, Ruth U. 2006. A new Greenland ice core chronology for the last glacial termination. Journal of Geophysical Research 111: D06102, doi:10.1029/ 2005JD006079.

Reimer PJ, Baillie MGL, Bard E, Bayliss A, Beck JW, Blackwell PG, Bronk Ramsey C, Buck CE, Burr GS, Edwards RL, Friedrich M, Grootes PM, Guilderson TP, Hajdas I, Heaton TJ, Hogg AG, Hughen KA, Kaiser KF, Kromer B, McCormac FG, Manning SW, Reimer RW, Richards DA, Southon JR, Talamo S, Turney CSM, van der Plicht J, Weyhenmeyer CE. 2009. Intcal09 and Marine09 radiocarbon age calibration curves, 0-50,000 years cal BP. Radiocarbon 51(4): 1111-50.

Renberg I. 1982. Varved lake sediments: geochronological record of the Holocene. Geologiska Föreningens $i$ Stockholm Förhandlingar 104:275-9.

Snowball I, Sandgren P. 2002. Geomagnetic field variations in northern Sweden during the Holocene quantified from varved lake sediments and their implications for cosmogenic nuclide production rates. The $\mathrm{Ho}$ locene 12(5):517-30.

Snowball I, Sandgren P, Petterson G. 1999. The mineral magnetic properties of an annually laminated Holocene lake-sediment sequence in northern Sweden. The Holocene 9(3):353-62.
Snowball I, Zillén L, Gaillard M-J. 2002. Rapid earlyHolocene environmental changes in northern Sweden based on studies of two varved lake-sediment sequences. The Holocene 12(1):7-16.

Snowball I, Zillén L, Ojala A, Saarinen T, Sandgren P. 2007. FENNOSTACK and FENNORPIS: varve dated Holocene palaeomagnetic secular variation and relative palaeointensity stacks for Fennoscandia. Earth and Planetary Science Letters 255(1-2):106-16.

Snowball I, Muscheler R, Zillén L, Sandgren P, Stanton T, Ljung K. 2010. Radiocarbon wiggle matching of Swedish lake varves reveals asynchronous climate changes around the $8.2 \mathrm{kyr}$ cold event. Boreas 39(4): 720-33.

Speranza A, van der Plicht J, van Geel B. 2000. Improving the time control of the Subboreal/Subatlantic transition in a Czech peat sequence by ${ }^{14} \mathrm{C}$ wiggle-matching. Quaternary Science Reviews 19(16):1589-604.

Stanton T, Snowball I, Zillén L, Wastegård S. 2010. Validating a Swedish varve chronology using radiocarbon, palaeomagnetic secular variation, lead pollution history and statistical correlation. Quaternary Geochronology 5(6):611-24.

Törnqvist TE. 1992. Accurate dating of organic deposits by AMS ${ }^{14} \mathrm{C}$ measurement of macrofossils. Radiocarbon 34(3):566-77.

Unkel I. 2006. AMS- ${ }^{14} \mathrm{C}$-Analysen zur Rekonstruktion der Landschafts- und Kulturgeschichte in der Region Palpa (S-Peru) [PhD dissertation]. Heidelberg: Ruprecht-Karls-Universität.

van Geel B, Mook WG. 1989. High-resolution ${ }^{14} \mathrm{C}$ dating of organic deposits using natural atmospheric ${ }^{14} \mathrm{C}$ variations. Radiocarbon 31(2):151-5.

van Geel B, Buurman J, Waterbolk HT. 1996. Archaeological and palaeoecological indications of an abrupt climate change in the Netherlands, and evidence for climatological teleconnections around 2650 BP. Journal of Quaternary Science 11(6):451-60.

van Geel B, van der Plicht J, Kilian MR, Klaver ER, Kouwenberg JHM, Renssen H, Reynaud-Farrera I, Waterbolk HT. 1998. The sharp rise of ${ }^{14} \mathrm{C}$ ca. $800 \mathrm{cal} \mathrm{BC}$ : possible causes, related climatic teleconnections and the impact on human environments. Radiocarbon 40(1):535-50.

van Geel B, Raspopov OM, Renssen H, van der Plicht J, Dergachev VA, Meijer HAJ. 1999. The role of solar forcing upon climate change. Quaternary Science Reviews 18(3):331-8.

Wacker L, Christl M, Synal H-A. 2010. Bats: a new tool for AMS data reduction. Nuclear Instruments and Methods in Physics Research B 268(7-8):976-9.

Zillén L, Snowball I, Sandgren P, Stanton T. 2003. Occurrence of varved lake sediment sequences in Värmland, west central Sweden: lake characteristics, varve chronology and AMS radiocarbon dating. Boreas 32(4):612-26. 